\title{
EFFECTS OF DRUGS ON THE ACCUMULATION AND SPONTANEOUS RELEASE OF NORADRENALINE IN THE RAT ANOCOCCYGEUS MUSCLE
}

\author{
S.A. DOGGRELL' \& G.N. WOODRUFF
}

Department of Physiology and Biochemistry, University of Southampton, Bassett Crescent East, Southampton SO9 3TV

1 The ability of drugs to inhibit noradrenaline accumulation and to release noradrenaline was studied in the isolated anococcygeus muscle of the rat.

2 Noradrenaline, tyramine, 2-amino,6,7-dihydroxy-1,2,3,4-tetrahydronaphthalene (ADTN), 2-amino,6,7-dimethoxy-1,2,3,4-tetrahydronaphthalene (dimethyl ADTN), and 5-hydroxytryptamine were all potent inhibitors of noradrenaline accumulation and potent releasers of noradrenaline. ADTN was accumulated by the rat isolated anococcygeus muscle.

3 Amphetamine and desipramine were potent inhibitors of noradrenaline accumulation but poor releasers of noradrenaline.

4 Methoxamine, oxymetazoline, acetylcholine, and angiotensin were poor inhibitors of noradrenaline accumulation and did not release noradrenaline.

5 The mechanism of action of these drugs is discussed.

\section{Introduction}

The ability of sympathomimetic drugs to inhibit noradrenaline uptake does not necessarily reflect their ability to be accumulated by noradrenergic neurones or to release noradrenaline. For instance, amphetamine has been shown to be a potent inhibitor of noradrenaline uptake (Burgen \& Iversen, 1965) but Ross \& Renyi (1966) and Thoenen, Hürliman \& Haefely (1968) were unable to demonstrate active transport of amphetamine into noradrenergic neurones.

The rat anococcygeus muscle is contracted by sympathomimetic drugs, 5-hydroxytryptamine, acetylcholine, angiotensin and by 2-amino,6,7-dihydroxy1,2,3,4-tetrahydronaphthalene (ADTN, a dopamine analogue). Some of these drugs may owe part or all of their spasmogenic activity to an ability to release noradrenaline. In the present paper, we describe the effect of these drugs and desipramine (which does not contract the muscle) on the accumulation and spontaneous release of noradrenaline in the rat anococcygeus muscle.

\footnotetext{
${ }^{1}$ Present address: Department of Pharmacology \& Clinical Pharmacology, School of Medicine, The University of Auckland, Private Bag, Auckland, New Zealand.
}

\section{Methods}

Male rats (about $350 \mathrm{~g}$ ) were killed and the anococcygeus muscles dissected out as described by Gillespie (1972).

\section{2-Amino,6,7-dihydroxy-1,2,3,4-tetrahydronaphthalene $(A D T N)$ and noradrenaline accumulation}

The accumulation of radioactivity in the rat anococcygeus muscle was measured as described by Doggrell \& Woodruff (1977). Thus, rat isolated anococcygeus muscles, weighing $10-20 \mathrm{mg}$ each, were mounted on wire frames under 0.2 to $0.5 \mathrm{~g}$ tension in $5 \mathrm{ml}$ of Krebs solution, gassed with $95 \% \mathrm{O}_{2}$ and $5 \% \mathrm{CO}_{2}$. Tritiated (-)-noradrenaline (final concentration of 61 $\mathrm{pmol} / \mathrm{ml}$ ) or ADTN (final concentration of 10,000 , 20,000 or $40,000 \mathrm{~d} \mathrm{~min}^{-1} \mathrm{ml}^{-1}$ ) was added for the appropriate length of time and then the muscles were blotted and washed for $10 \mathrm{~min}$ in $5 \mathrm{ml}$ of Krebs solution. The muscle was then blotted dry and weighed. The radioactivity in both the tissue and the medium was determined, expressed as nmol noradrenaline or ADTN $\mathrm{d} \min ^{-1} \mathrm{~g}^{-1}$ tissue, and the tissue:medium ratios were calculated. 
When studying the effects of drugs on noradrenaline accumulation, different concentrations of these drugs were added to the Krebs solution during the incubation with tritiated noradrenaline. Inhibition of noradrenaline accumulation was expressed as a percentage of control values. Lines were drawn of $\%$ inhibition of noradrenaline accumulation against $\log \mathrm{M}$ concentration of uptake inhibitors. The $\mathrm{IC}_{50}$ values (concentration causing $50 \%$ inhibition of noradrenaline accumulation) for each drug were calculated from regression lines.

\section{Spontaneous release of noradrenaline}

The spontaneous release of radioactivity was measured as follows. Individual anococcygeus muscles were mounted under 0.2 to $0.5 \mathrm{~g}$ tension in Krebs solution at $37^{\circ} \mathrm{C}$, gassed with $95 \% \mathrm{O}_{2}$ and $5 \%$ $\mathrm{CO}_{2}$. Tritiated noradrenaline (final concentration of $122 \mathrm{pmol} / \mathrm{ml}$ ) was added to a final volume of $5 \mathrm{ml}$ and the mixture incubated for 30 minutes. The muscles were then transferred to a further $5 \mathrm{ml}$ of Krebs solution, prewarmed to $37^{\circ} \mathrm{C}$ and gassed with $95 \% \mathrm{O}_{2}$ and $5 \% \mathrm{CO}_{2}$. The replacement of the Krebs solution was repeated at $5 \mathrm{~min}$ intervals for 80 minutes.

When studying the effect of drugs on spontaneous release, $40 \mathrm{~min}$ after the Krebs solution replacement procedure had begun, solution containing an appropriate concentration of the drug was substituted for the drug-free solution for a period of 20 minutes; 1 $\mathrm{ml}$ of medium from each $5 \mathrm{~min}$ incubation $(0-80 \mathrm{~min})$ was added to $10 \mathrm{ml}$ of scintillation fluid and the radioactivity counted in a Phillips scintillation counter. The tissue was blotted and weighed at the end of the experiment. Release, in the presence and absence of drugs, was expressed as pmol noradrenaline released/g tissue. Differences were analysed with Student's $t$ test and regarded as significant wherever $P<0.05$.

\section{Drugs}

$(-)-\left[7-{ }^{3} \mathrm{H}\right]$-noradrenaline hydrochloride (specific activity $10.3 \mathrm{Ci} / \mathrm{mmol}$ ) and $\left[{ }^{3} \mathrm{H}\right]$-2-amino,6,7-dihydroxy-1,2,3,4-tetrahydronaphthalene hydrobromide were obtained from Amersham.

The other drugs used were oxymetazoline hydrochloride (Allen \& Hanbury), methoxamine hydrochloride (Burroughs-Wellcome), angiotensin II, desipramine hydrochloride (Ciba-Geigy), (-)-noradrenaline bitartrate, amphetamine sulphate, 5-hydroxytryptamine creatinine sulphate, tyramine hydrochloride (Koch-Light), acetylcholine chloride (Sigma), 2-amino,6,7-dihydroxy-1,2,3,4-tetrahydronaphthalene hydrobromide (ADTN) and 2-amino, 6,7-dimethoxy-

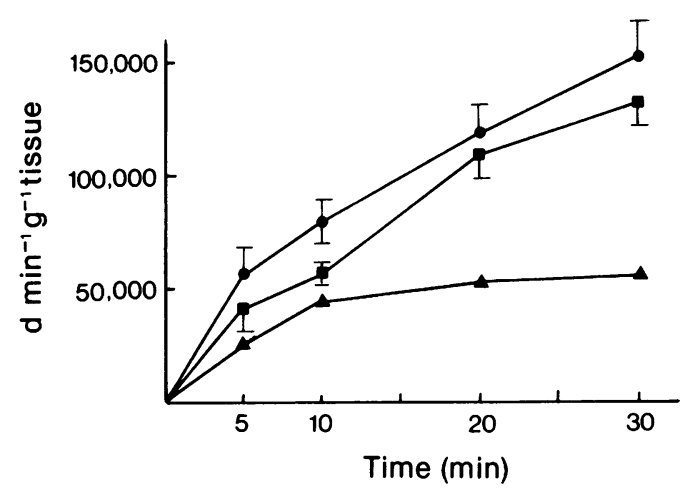

Figure 1 Time course of accumulation of radioactivity in the rat anococcygeus muscle following incubation in tritiated ADTN at the following concentrations: (A) $10,000 \mathrm{~d} \mathrm{~min}^{-1} \mathrm{ml}^{-1}$; (ロ) 20,000 d $\min ^{-1} \mathrm{ml}^{-1}$; (O) $40,000 \mathrm{~d} \mathrm{~min}^{-1} \mathrm{ml}^{-1}$. Each point is the mean of $4-8$ observations. Vertical lines show s.e. means.

1,2,3,4-tetrahydronaphthalene hydrochloride (dimethyl ADTN).

The Krebs solution had the following composition $(\mathrm{g} / \mathrm{l}): \mathrm{CaCl}_{2} .6 \mathrm{H}_{2} \mathrm{O} 0.55, \mathrm{KCl} 0.35, \mathrm{KH}_{2} \mathrm{PO}_{4} 0.16$, $\mathrm{MgSO}_{4} .7 \mathrm{H}_{2} \mathrm{O} 0.29, \mathrm{NaHCO}_{3} 2.1, \mathrm{NaCl} 7.1$ and glucose, 1.0.

\section{Results}

Time course of 2-amino,6,7-dihydroxy-1,2,3,4-tetrahydronaphthalene $(A D T N)$ accumulation

Following incubation in the presence of $\left[{ }^{3} \mathrm{H}\right]$-ADTN (final concentration of $10,000,20,000$ or 40,000 $\mathrm{d} \mathrm{min}^{-1} \mathrm{ml}^{-1} ; 10,000 \mathrm{~d} \mathrm{~min}^{-1} \mathrm{ml}^{-1}$ is equivalent to approximately $50 \mathrm{pmol} / \mathrm{ml}$ ), the rat anococcygeus muscle accumulated tritium (Figure 1). The highest tissue: medium ratio of $5.0 \pm 0.5$ (s.e. mean, $n=8$ ) was obtained with $20,000 \mathrm{~d} \mathrm{~min}^{-1} \mathrm{ml}^{-1}$.

\section{Inhibition by drugs of noradrenaline accumulation}

Desipramine was the most potent drug examined, being over a 100 times more potent than unlabelled noradrenaline, in inhibiting tritiated noradrenaline accumulation (Figure 2a). ADTN, amphetamine, tyramine, and 5-hydroxytryptamine all had potencies similar to unlabelled noradrenaline (within a 10 fold range) whilst oxymetazoline, dimethyl ADTN, methoxamine (Figure 2a), and acetylcholine were poor inhibitors of noradrenaline accumulation. The $O$ methylation of the phenolic hydroxyl groups of ADTN to form dimethyl ADTN led to a large decrease (approximately 100 fold) in ability to inhibit 

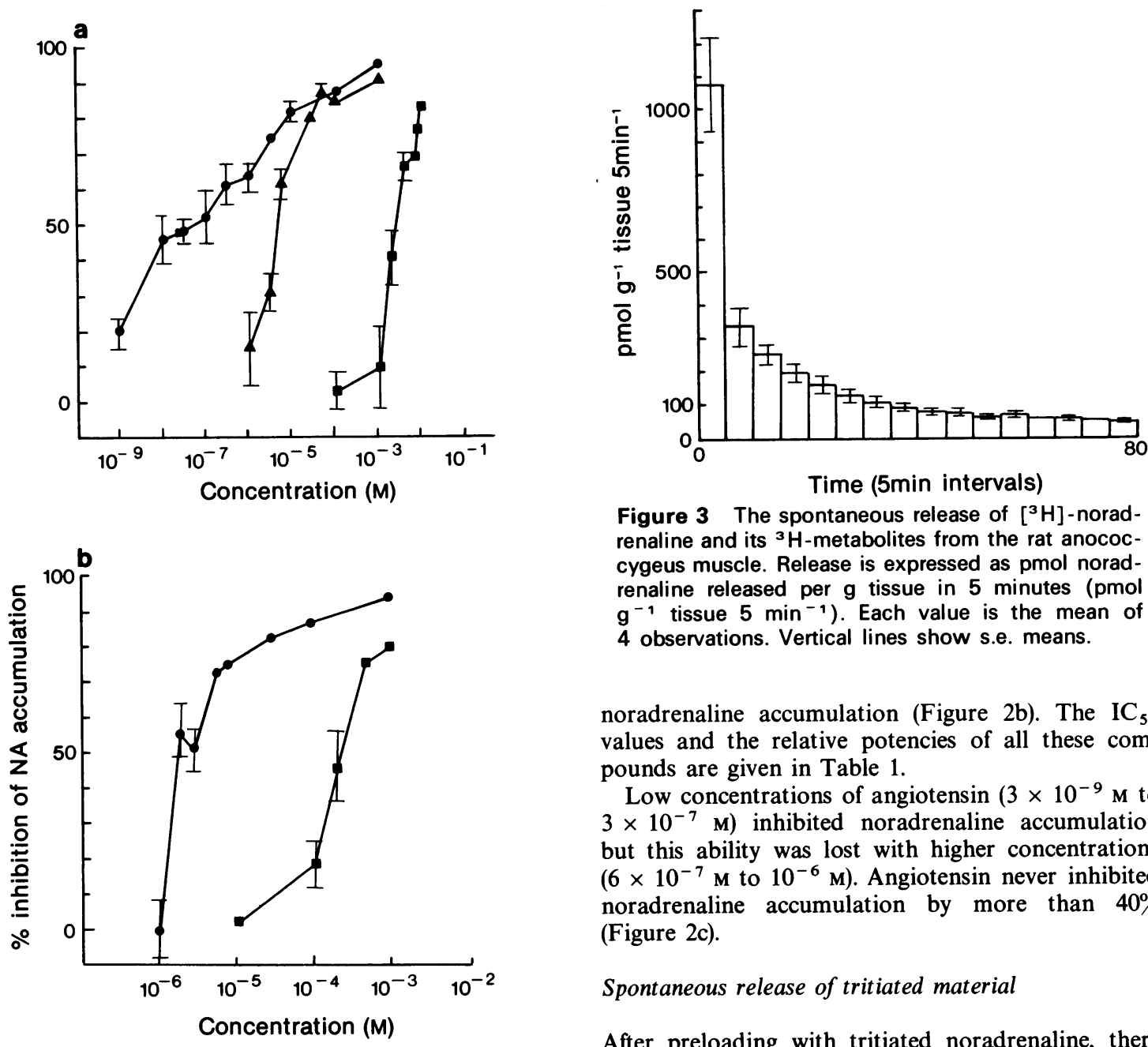

Figure 3 The spontaneous release of $\left[{ }^{3} \mathrm{H}\right]$-noradrenaline and its ${ }^{3} \mathrm{H}$-metabolites from the rat anococcygeus muscle. Release is expressed as pmol noradrenaline released per $\mathrm{g}$ tissue in 5 minutes ( $\mathrm{pmol}$ $\mathrm{g}^{-1}$ tissue $5 \mathrm{~min}^{-1}$ ). Each value is the mean of 4 observations. Vertical lines show s.e. means.

noradrenaline accumulation (Figure 2b). The $\mathrm{IC}_{50}$ values and the relative potencies of all these compounds are given in Table 1.

Low concentrations of angiotensin $\left(3 \times 10^{-9} \mathrm{M}\right.$ to $\left.3 \times 10^{-7} \mathrm{M}\right)$ inhibited noradrenaline accumulation but this ability was lost with higher concentrations $\left(6 \times 10^{-7} \mathrm{M}\right.$ to $\left.10^{-6} \mathrm{M}\right)$. Angiotensin never inhibited noradrenaline accumulation by more than $40 \%$ (Figure 2c).

\section{Spontaneous release of tritiated material}

After preloading with tritiated noradrenaline, there was a rapidly declining release of tritiated material for the first $30 \mathrm{~min}$ which was followed by a period during which the release declined slowly (Figure 3). Terming the period $35-50 \mathrm{~min}$ as the control period, no further significant reduction in release was observed during the next 30 minutes.

Figure 2 Dose-response curves for the inhibition by drugs of noradrenaline (NA) accumulation in rat anococcygeus muscle: (a) (O) Desipramine; (A) noradrenaline; ( $\square$ ) methoxamine; (b) (O) ADTN; (a) dimethyl ADTN; (c) (O) angiotensin. Each point is the mean of 4 observations and vertical lines show s.e. means. Inhibition in the presence of a drug was calculated as the \% of control measured in the absence of drug when tissues were incubated for $20 \mathrm{~min}$ in $\left[{ }^{3} \mathrm{H}\right]$-noradrenaline, 61 $\mathrm{pmol} / \mathrm{ml}$. 

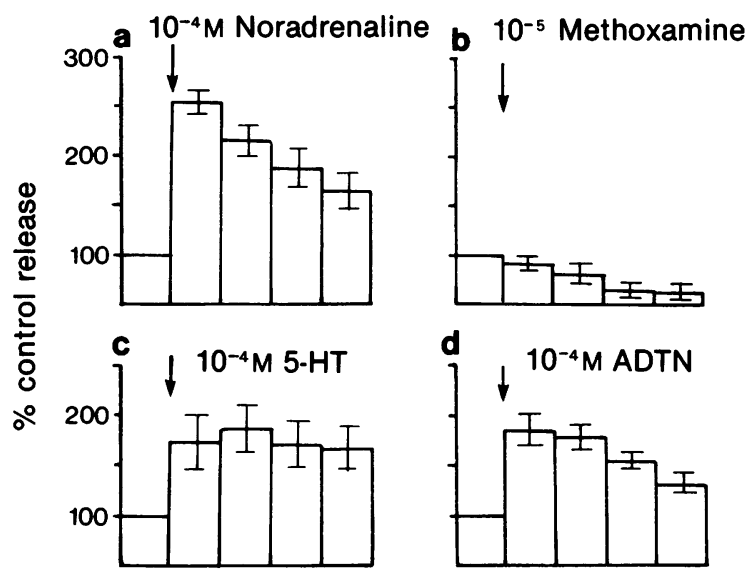

Figure 4 The effect of drugs on the spontaneous release of $\left[{ }^{3} \mathrm{H}\right]$-noradrenaline and its ${ }^{3} \mathrm{H}$-metabolites from rat anococcygeus muscle: (a) noradrenaline, (b) methoxamine, (c) 5-hydroxytryptamine (5-HT), and (d) ADTN. Release in the presence of drugs $/ 5$ min was calculated as \% control release (release observed in $5 \mathrm{~min}$ period before addition of drug). Each value is the mean of 4 observations. Vertical lines show s.e. means.

Effects of drugs on spontaneous release of tritiated material

Drugs were used in concentrations which we had previously observed to give the maximal contractile response in rat anococcygeus muscle. Unlabelled noradrenaline $\left(10^{-4} \mathrm{M}\right)$, tyramine $\left(3 \times 10^{-4} \mathrm{M}\right)$, ADTN

Table 1 Inhibition of noradrenaline accumulation by drugs

\section{Drug}

Desipramine
ADTN
Amphetamine
Noradrenaline
Tyramine
5-Hydroxytryptamine
Oxymetazoline
Dimethyl ADTN
Methoxamine
Acetylcholine

Desipramine

ADTN

Amphetamine

Tyramine

5-Hydroxytryptamine

Methoxamine

Potency is expressed as IC 50 values and as the equipotent molar ratio (e.p.m.r.) which is $\mathrm{IC}_{50}$ for drug/ $\mathrm{IC}_{\mathrm{5} \text { o }}$ noradrenaline.

Values were calculated from regression lines and involved at least 4 separate determinations for each compound. $\left(10^{-4} \mathrm{M}\right)$, dimethyl ADTN $\left(10^{-3} \mathrm{M}\right)$, and 5-hydroxytryptamine $\left(10^{-4} \mathrm{M}\right)$ were able to release tritiated material but methoxamine $\left(10^{-5} \mathrm{M}\right)$, oxymetazoline $\left(3 \times 10^{-8} \mathrm{M}\right)$, acetylcholine $\left(10^{-2} \mathrm{M}\right)$, and angiotensin $\left(3 \times 10^{-7} \mathrm{M}\right)$ did not release radioactivity. The effect of noradrenaline, methoxamine, 5-hydroxytryptamine, and ADTN on spontaneous release is illustrated in Figure 4.

Amphetamine $\left(3 \times 10^{-5} \mathrm{M}\right)$, a concentration which gave a maximal contractile response of rat anococcygeus muscle, did not release tritiated material although a higher concentration of amphetamine $\left(10^{-3} \mathrm{M}\right)$ did. Desipramine $\left(10^{-6} \mathrm{M}\right)$ neither contracted the rat anococcygeus muscle nor released tritiated material.

\section{Discussion}

The rat anococcygeus muscle is contracted by sympathomimetic drugs, 5-hydroxytryptamine, acetylcholine, angiotensin and by ADTN (a dopamine analogue). It is conceivable that drugs which release noradrenaline from storage sites within a tissue and which reduce the reuptake of noradrenaline might owe part or all of their spasmogenic activity to the released amines. Therefore several drugs were studied in these respects in the rat anococcygeus muscle.

The accumulation of noradrenaline from low concentrations of the amine by the rat anococcygeus muscle is predominantly neuronal (Nash, Gillespie \& Robertson, 1974). Furthermore, following incubation with low concentrations of tritiated noradrenaline, all the radioactivity in the rat anococcygeus muscle behaves as authentic noradrenaline (Doggrell \& Woodruff, 1977). In the present paper, we used a low concentration of noradrenaline in order to study neuronal accumulation.

Many sympathomimetic drugs (e.g. metaraminol, amphetamine, tyramine) are potent inhibitors of neuronal noradrenaline uptake (Burgen \& Iversen, 1965) whereas methoxamine (Trendelenburg, Maxwell \& Pluchino, 1970) and oxymetazoline (Gibson \& Pollock, 1973) are not. Desipramine (Maxwell, Chaplin, Eckhardt, Soares \& Hite, 1970) and angiotensin (Palaic \& Khairallah, 1967) have also been reported to inhibit presynaptic uptake of noradrenaline. However, inhibitors of uptake are themselves not necessarily substrates for the accumulation process e.g. tricyclic antidepressants (Biel \& Bopp, 1974). Furthermore, the ability of a drug to inhibit noradrenaline accumulation does not necessarily reflect an ability to release noradrenaline. The drugs used in this study may be divided into 3 groups on the basis of their abilities to inhibit accumulation of and cause release of noradrenaline.

Firstly, oxymetazoline, methoxamine, acetylcholine 
and angiotensin were relatively weak in both respects. It would therefore seem likely that their spasmogenic activity is unrelated to indirect sympathomimetic actions in this isolated tissue. Although the ability of angiotensin both to inhibit neuronal uptake and to release noradrenaline has been demonstrated in several tissues (for references see Starke, 1977), in the present study, using rat anococcygeus muscle, angiotensin did neither.

Secondly, amphetamine and desipramine were respectively equipotent with and 100 times more active than noradrenaline itself in inhibiting accumulation but neither of them released noradrenaline. Although, amphetamine is a potent inhibitor of noradrenaline uptake (Burgen \& Iversen, 1965), most experiments have failed to demonstrate that amphetamine is actively transported into noradrenergic neurones (Ross \& Renyi, 1966; Thoenen et al., 1968). Recently, Azzaro, Ziance \& Rutledge (1974) have provided some evidence for the active transport of amphetamine in synaptosomes of rat cerebral cortex. However, in the present study, the release of noradrenaline by amphetamine could only be demonstrated with concentrations higher than those necessary for maximum contractile responses. Thus, the release of noradrenaline by amphetamine does not appear to be important for its sympathomimetic actions in this isolated tissue.

Thirdly, 5-hydroxytryptamine, ADTN, dimethyl
ADTN, and tyramine were potent both in inhibiting accumulation and releasing noradrenaline. 5- $\mathrm{Hy}-$ droxytryptamine is transported by the noradrenaline accumulation process (Axelrod \& Inscoe, 1963). Paton (1973) demonstrated that 5-hydroxytryptamine releases noradrenaline in rabbit atria. The contractile responses to 5-hydroxytryptamine in the rat anococcygeus muscle are inhibited in the presence of the uptake inhibitor nortriptyline and following 6-hydroxydopamine preincubation (Doggrell \& Woodruff, unpublished observations). These results suggest that 5-hydroxytryptamine acts solely by releasing noradrenaline in rat anococcygeus muscle.

Indirect sympathomimetic actions of the powerful dopamine receptor agonist, ADTN, have been postulated by Doggrell \& Woodruff (1976). They demonstrated that the contractile responses to ADTN in the rat anococcygeus muscle were inhibited by phentolamine, nortriptyline, and following 6-hydroxydopamine preincubation. In the present study, $\left[{ }^{3} \mathrm{H}\right]-A D T N$ was accumulated by the rat anococcygeus muscle in a similar manner to that described previously for noradrenaline (Doggrell \& Woodruff, 1977). Thus, there is conclusive evidence for indirect sympathomimetic actions of ADTN.

We are grateful to the following for gifts of drugs: Allen \& Hanbury and Burroughs-Wellcome. One of us (S.A.D.) was supported by a M.R.C. research award.

\section{References}

AXELROD, J. \& INSCOE, J.K. (1963). The uptake and binding of circulating serotonin and the effects of drugs. J. Pharmac. exp. Ther., 141, 161-165.

AZZARO, A.J., ZIANCE, R.T. \& RUTLEDGE, C.O. (1974). The importance of neuronal uptake of amines for amphetamine-induced release of ${ }^{3} \mathrm{H}$-norepinephrine from isolated brain tissue. J. Pharmac. exp. Ther., 189, 110-118.

BIEL, J.H. \& BOPP, B. (1974). Antidepressant drugs. In Psychopharmacological Agents. ed. Gordon, M., pp. 283-341. New York: Academic Press.

BURGEN, A.S.V. \& IVERSEN, L.L. (1965). The inhibition of noradrenaline uptake by sympathomimetic amines in the rat isolated heart. Br. J. Pharmac. Chemother., 25, $34-49$.

DOGGRELL, S.A. \& WOODRUFF, G.N. (1976). Studies on noradrenaline uptake and release in the rat anococcygeus muscle. J. Physiol., 259, 59-60P.

DOGGRELL, S.A. \& WOODRUFF, G.N. (1977). Effects of antidepressant drugs on noradrenaline accumulation and contractile responses in the rat anococcygeus muscle. Br. J. Pharmac., 59, 403-409.

GIBSON, A. \& POLLOCK, D. (1973). The absence of cocaine- and 6-hydroxydopamine-induced supersensitivity to oxymetazoline in the rat anococcygeus muscle. Br. J. Pharmac., 49, 726-727P.

GILLESPIE, J.S. (1972). The rat anococcygeus muscle and

its response to nerve stimulation and to some drugs. Br. J. Pharmac., 45, 404-416.

MAXWELL, R.A., CHAPLIN, E., ECKHARDT, S.B., SOARES, J.R. \& HITE, G. (1970). Conformational similarities between molecular models of phenethylamine and of potent inhibitors of the uptake of tritiated norepinephrine by adrenergic nerves in rabbit aorta. J. Pharmac. exp. Ther., 173, 158-165.

NASH, C.W., GILlESPIE, J.S. \& ROBERTSON, E.N. (1974). Noradrenaline uptake properties of the anococcygeus muscle of the rat. Can. J. Physiol. Pharmac., 52, 430-440.

PALAIC, D. \& KHAIRALlAH, P.A. (1967). Inhibition of noradrenaline uptake by angiotensin. J. Pharm. Pharmac., 19, 396-397.

PATON, D.M. (1973). Effect of substituted tryptamine on the efflux of noradrenaline from adrenergic nerves in rabbit atria. J. Pharm. Pharmac., 25, 905-907.

ROSS, S.B. \& RENYI, A.L. (1966). Uptake of tritiated tyramine and $(+)$-amphetamine by mouse heart slices. $J$. Pharm. Pharmac., 18, 756-757.

STARKE, K. (1977). Regulation of noradrenaline release by presynaptic receptor systems. Rev. Physiol. Biochem. Pharmac., 77, 1-124.

THOENEN, H., HÜRLIMAN, A. \& HAEFELY, W. (1968). Mechanism of amphetamine accumulation in the iso- 
lated perfused heart of the rat. J. Pharm. Pharmac., 20, 1-11.

TRENDELENBURG, U., MAXWELL, R.A. \& PLUCHINO, S. (1970). Methoxamine as a tool to assess the importance of intraneuronal uptake of 1-norepinephrine in the cat's nictitating membrane. J. Pharmac. exp. Ther., 172, 91-99.

(Received October 10, 1977. Revised December 5, 1977.) 